\title{
スピン飛しょう体のインパルス制御源による姿勢制御システムの設計*1 Design of Attitude Control System for Spinning Vehicle by Combination of One-Shot Thrusters
}

\author{
田中秀 樹*2 - 狼 嘉 彰*3 松 永三郎*3 \\ Hideki TanaKa, Yoshiaki OhKami and Saburo Matunaga
}

Key Words : Rockets, Simulation, Attitude Control, Thruster

\begin{abstract}
The main feature of one-shot thrusters is discreteness in both time and space domain. We apply discrete-time sliding mode control to the attitude control of a spinning vehicle. And we consider the space discreteness by applying a simple selection algorithm (SSA) to the selection of the combination of one-shot thrusters prearranged on the vehicle in order to generate the control force. SSA is the new algorithm we proposed, and its calculation load is light in computation load. We adopt a regulator scheme to reject disturbances of precession for a LUNAR-A type penetrator, and conduct numerical simulations of the problem to show the effectiveness of the proposed control algorithm for one-shot thrusters.
\end{abstract}

\section{1.はじめに}

既存の気象観測等の飛しょう体や宇宙機の姿勢制御用ア クチュエータとして用いられているフィン（大気環境下）, 連続噴射スラスタやホイール等は、機構が複雑で高価であ る.これに対し、インパルス型サイドスラスタは制御力を 推進薬の燃焼により直接得るため, 搭載体積, 重量が小さ く安価であり，高高度，低動圧下や超高速の飛しょう体に 有効である( ${ }^{1 \sim 4}$. この制御源は, 超小型のロケットモータ によりインパルス状に推力を発生し，1度噴射すると使用 できない。

このようなインパルス制御源は，複数個を飛しょう体側 面に並へて各方向に噴射できるように機体をスピンさせな

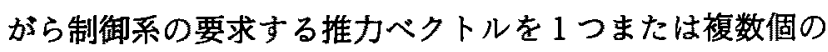
インパルス制御源の組合せで発生させるため，時間的離散 性と空間的離散性という特徴を持つ5 7). 本論文では，こ のインパルス制御源を用いたスピン飛しょう体の姿勢制御 システムの構築を目的として，インパルス制御源の時間的 離散性と空間的離散性を考慮し, 制御系にスライディング モード制御5,7ー14)を、制御源の選択法に本論文で提案する 単純選択アルゴリズム（SSA：Simple Selection Algorithm）を用いる。スライディングモード制御では，実シ ステムてのコンピュータ使用を考慮して離散時間系で制御 系を設計し，ある範囲内に極配置する 2 次形式評価関数の 最適制御の方法15) を用いた切換超平面の設計5,7,9,13,14)によ り制御源の消費推力が小さくなることも示す。これは実際

\footnotetext{
*1 平成 9 年 10 月 20 日, 第 41 回宇宙科学技術連合講演会にて発表. 平成 10 年 3 月 23 日原稿受理

*2 日産自動車 $($ 株)

*3 東京工業大学
}

のシステムでは飛しょう体の全備重量を抑えることに有効 である、制御源選択の問題は一種の組合せ最適問題に帰着 され，一般的には解析的に解くことは事実上困難であるた

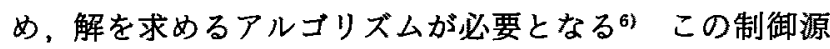
の選択には単純遺伝的アルゴリズム (SGA: Simple Genetic Algorithm) ${ }^{16 \sim 18)}$ も適用可能であることを筆者ら は報告した ${ }^{6,7)}$ が、計算負荷が非常に大きく，実装するた めにはソフトとハード面で最適化を図らなければならな い、そこで本論文では SGAに比べ計算負荷が非常に少な く実用的なアルゴリズムの SSA を提案し，SGA と比べ てもほほ同様に有効であることを示す。

本解析ての姿勢制御系構成の概要を第 1 図に示す。制御 対象となるプラントとして，月探查宇宙機である LUNAR-A ${ }^{19,20)}$ を用い，初期外乱を受け歳差運動する機 体を初期平衡状態に戻すレギニレータ問題を取り上げる. コントローラは初期平衡状態量のずれから一定の制御間隔 で要求推力を算出し、インパルス制御源の点火選択を SSA により決定する。ここで，LUNAR-A は本論文の例 題として選んだものであり，実際の姿勢制御系は文献 20) 等を参照して頂きたい.

\section{2. 解 析 対 象}

本論文では 3 次元 6 自由度の飛しょう解析を行う．解析 対象の飛しょう体として月探查宇宙機である LUNAR-A を取り上げ，第 1 表に示す諸元 ${ }^{19,20)}$ を用いる．本解析では インパルス制御源を重心より $350 \mathrm{~mm}$ 前方と後方に配置 し、ピッチ，ヨーの制御を行う(第 2 図参昭).また, 仮 定として

・機体運動に関する仮定

仮定 1：飛しょう体のスピンレートは一定である. 


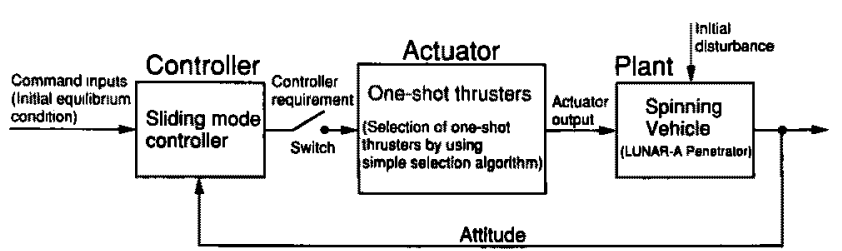

第 1 図 スピン飛しょう体の姿勢制御系の構成

第 1 表 スビン飛しょう体 (LUNAR-A) の諸元

\begin{tabular}{lcc}
\multicolumn{1}{c}{ Parameter } & Symbol & Value \\
\hline Spin rate & $\omega$ & $120 \mathrm{rpm}$ \\
Mass & $m$ & $21.2 \mathrm{~kg}$ \\
& $I_{x x}$ & $0.111 \mathrm{~kg} \cdot \mathrm{m}^{2}$ \\
Moment of inertia & $I_{y y}$ & $2.029 \mathrm{~kg} \cdot \mathrm{m}^{2}$ \\
Impact velocity & $U_{0}$ & $280-300 \mathrm{~m} / \mathrm{s}$ \\
\hline
\end{tabular}

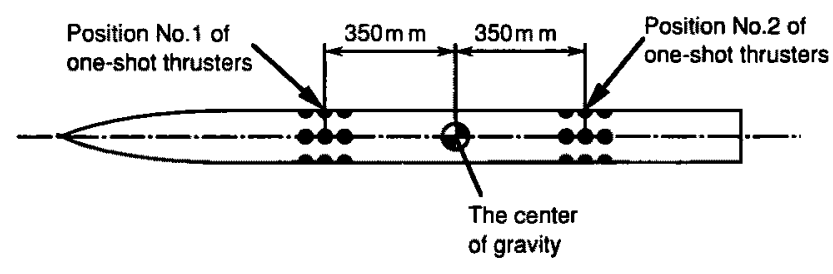

第 2 図 インパルス制御源を搭載したスピン飛しょう体の概要図

仮定 $2 ：$ 機体は剛体で軸対称である。

仮定 3 ：飛しょう体の質量変化はない.

・制御系に関する仮定

仮定 $4:$ 制御に用いる状態変数は入手できる.

仮定 5：制御源はピッチ, ヨー方向に時間遅れなく発生 できる。

とする．また，飛しょう環境は月を想定し空気力は働かな いものとする。ここで，仮定 4，5 は LUNAR-A 等の実 際の問題では満たされにくく，仮定 4 にちいては現実に重 量の制約から利用可能なセンサは限られ，入手できる状態 変数に制約がある。 また，仮定 5 に対しては制御アクチュ エータの応答遅れは避けられない問題であり, 高スピン状 態での姿勢制御誤差に対して応答遅れは大きな感度を持 つ、しかし，本論文では新しいインパルス制御源の制御シ ステム構築ということで理想的な仮定をおいた。

本問題での制御要求は外乱発生 $2 \mathrm{~s}$ 以内に迎角，横滑り 角ともに $0.1 \mathrm{rad}$ 以下にすることである.

2.1 運動方程式 本節では 3 次元 6 自由度の運動方程 式を導き，微小擾乱の仮定の下に運動方程式を線形化す

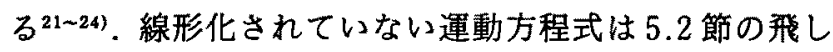
よう解析に，線形運動方程式は 3 章の制御系の設計と 5.1 節に用いられる。

運動方程式をたてるに当たり，地球(月)の公転や自転の 影響を無視できると仮定し，地球上に固定された局地座標 系を基準座標系 (慣性系) $\left(X_{\mathrm{E}}, Y_{\mathrm{E}}, Z_{\mathrm{E}}\right)$ とする，機体標系 $\left(X_{\mathrm{B}}, Y_{\mathrm{B}}, Z_{\mathrm{B}}\right)$ (機体座標系 $X_{\mathrm{B}}$ 軸周りにスピンレート $\omega て$ 回転しない)をとる．ここで $\Psi, \Theta, Ф$ はオイラー角， $\omega$ はスピンレート，Q，Rはピッチ角速度とヨー角速度，U，
$V, W$ は各機軸方向の速度， $V_{\mathrm{c}}$ は重心の速度ベクトル， $\alpha, \beta$ 㹥迎角と横滑り角である。このような機体座標系を とることで飛しょう解析の時間刻みを大きくとることがて きる.この運動方程式は

$$
\begin{aligned}
& m(\dot{U}+Q W-R V)=-m g \sin \Theta \\
& m(\dot{V}+R U)=m g \cos \Theta \sin \Phi+F_{\text {jety1 }}+F_{\text {jety2 }} \\
& m(\dot{W}-Q U)=m g \cos \Theta \cos \Phi+F_{\text {jetz1 }}+F_{\text {jetz2 }} \\
& I_{y y} \dot{Q}=-I_{x x} R \omega-F_{\text {jetz1 }} l_{\text {jet }}+F_{\text {jetzz }} l_{\text {jet }} \\
& I_{y y} \dot{R}=I_{x x} Q \omega+F_{\text {jety } 1} l_{\text {jet }}-F_{\text {jety }} l_{\text {jet }}
\end{aligned}
$$

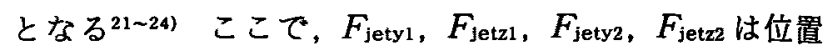
1 と 2 のサイドジェットの $Y_{\mathrm{B}}, Z_{\mathrm{B}}$ 軸方向の制御推力, $l_{\mathrm{jet}}$

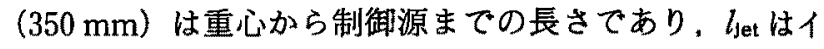
ンパルス制御源の各々が小さいとして一定とした.

2.2 線形化モテル 運動方程式 (1) 〜 (5) に対し, 我 しょう体の釣り合いからの微小摄乱を考元微小項を無視す ると線形化された運動方程式 ${ }^{21 ~ 24) ~}$ は

$$
\dot{\boldsymbol{x}}=\boldsymbol{A} \boldsymbol{x}+\boldsymbol{B u}
$$

$$
x=\left[\begin{array}{c}
u \\
\alpha \\
q \\
\theta \\
\beta \\
r \\
\psi
\end{array}\right], A=\left[\begin{array}{ccccccc}
0 & 0 & -W_{0} & -g & 0 & 0 & 0 \\
0 & 0 & 1 & 0 & 0 & 0 & 0 \\
0 & 0 & 0 & 0 & 0 & -\omega I_{x x} / I_{y y} & 0 \\
0 & 0 & 1 & 0 & 0 & 0 & 0 \\
0 & 0 & 0 & 0 & 0 & -1 & 0 \\
0 & 0 & \omega I_{x x} / I_{y y} & 0 & 0 & 0 & 0 \\
0 & 0 & 0 & 0 & 0 & 1 & 0
\end{array}\right]
$$$$
\boldsymbol{B}=\left[\begin{array}{cccc}
0 & 0 & 0 & 0 \\
0 & 0 & 1 / m U_{0} & 1 / m U_{0} \\
0 & 0 & -l_{\mathrm{jet}} / I_{y y} & l_{\mathrm{jet}} / I_{y y} \\
0 & 0 & 0 & 0 \\
1 / m U_{0} & 1 / m U_{0} & 0 & 0 \\
l_{\mathrm{jet}} / I_{y y} & -l_{\mathrm{jet}} / I_{y y} & 0 & 0 \\
0 & 0 & 0 & 0
\end{array}\right]
$$

$$
\boldsymbol{u}=\left[\begin{array}{c}
F_{\text {jety1 }} \\
F_{\text {jety2 }} \\
F_{\text {jetz1 }} \\
F_{\text {jetz2 }}
\end{array}\right]
$$

となる．ここで添字の０は各変数の定常值を，小文字は㩧 乱を表す．また，変数 $V_{0}, Q_{0}, R_{0}, \Psi_{0}, \Theta_{0}$ は定常值が ゼロとし， $U_{0}$ は $W_{0}$ よりも非常に大きいとして

$$
\alpha=w / U_{0}, \quad \beta=v / U_{0}
$$

とした.

\section{3. スライティングモード制御系の設計}

本章では離散時間系レギュレータ問題のスライディング モード制御系5,7 14)を設計する．離散時間系で設計するの は実システムに適用する場合にはコンピュータを用いて実 現されるからである。そこで連続時間系の式（6)の離散時 間系

$$
\boldsymbol{x}(k+1)=\emptyset \boldsymbol{x}(k)+\Gamma \boldsymbol{u}(k)
$$

に対し，制御系を設計する。ここで $x \in R^{n}, \Phi \in R^{n \times n}, \Gamma$ 
$\in \boldsymbol{R}^{n \times m}, n=7, m=4$ である。

3.1 切換超平面の設計 式(8)のシステムに対し，ス ライディングモードになってから, 評価関数

$$
J_{\mathrm{d}}=\sum_{k=k_{\mathrm{s}}}^{\infty} x(k)^{T} \boldsymbol{Q} x(k)
$$

を最小にする最適な切換超平面を設計5,7 9,13,14)する。たた し， $k_{\mathrm{s}}$ はスライディングモードが始まる時間であり，行 列 $\boldsymbol{Q}$ は対称正定值行列である.まず, 式 (8)を変換行列 $T$ により

$$
\begin{aligned}
& {\left[\begin{array}{c}
\bar{x}_{1}(k+1) \\
\bar{x}_{2}(k+1)
\end{array}\right]=\left[\begin{array}{ll}
\Phi_{11} & \Phi_{12} \\
\Phi_{21} & \Phi_{22}
\end{array}\right]\left[\begin{array}{l}
\bar{x}_{1}(k) \\
\bar{x}_{2}(k)
\end{array}\right]+\left[\begin{array}{l}
0 \\
\Gamma_{2}
\end{array}\right] \boldsymbol{u}(k)} \\
& \boldsymbol{x}(k)=\boldsymbol{T}^{-1}\left[\begin{array}{c}
\bar{x}_{1}(k) \\
\bar{x}_{2}(k)
\end{array}\right], \quad \boldsymbol{T} \Gamma=\left[\begin{array}{l}
0 \\
\Gamma_{2}
\end{array}\right], \\
& \boldsymbol{T} \Phi \boldsymbol{T}^{-1}=\left[\begin{array}{ll}
\Phi_{11} & \Phi_{12} \\
\Phi_{21} & \Phi_{22}
\end{array}\right]
\end{aligned}
$$

に変換する。このシステムに適用するため, 式 $(9)$ に同様 の変換を行うと

$$
\begin{aligned}
J_{\mathrm{d}}= & \sum_{k=k_{\mathrm{s}}}^{\infty} \overline{\boldsymbol{x}}(k)^{r} \overline{\boldsymbol{Q}} \overline{\boldsymbol{x}}(k) \\
= & \sum_{k=k_{\mathrm{s}}}^{\infty}\left\{\overline{\boldsymbol{x}}_{1}(k)^{T} \boldsymbol{Q}_{11} \overline{\boldsymbol{x}}_{1}(k)\right. \\
& \left.+2 \overline{\boldsymbol{x}}_{1}(k)^{T} \boldsymbol{Q}_{12} \overline{\boldsymbol{x}}_{2}(k)+\overline{\boldsymbol{x}}_{2}(k)^{T} \boldsymbol{Q}_{22} \overline{\boldsymbol{x}}_{2}(k)\right\} \\
\overline{\boldsymbol{Q}}= & \left(\boldsymbol{T}^{-1}\right)^{T} \boldsymbol{Q} \boldsymbol{T}^{-1}=\left[\begin{array}{ll}
\boldsymbol{Q}_{11} & \boldsymbol{Q}_{12} \\
\boldsymbol{Q}_{21} & \boldsymbol{Q}_{22}
\end{array}\right], \quad \boldsymbol{Q}_{21}^{T}=\boldsymbol{Q}_{12}
\end{aligned}
$$

となる.ここで $\overline{\boldsymbol{x}}_{1} \in \boldsymbol{R}^{n-m}, \overline{\boldsymbol{x}}_{2} \in \boldsymbol{R}^{m}, \Gamma_{2} \in \boldsymbol{R}^{m \times m}$ である.こ の評価関数を最小にする最適な切換超平面は

$$
\begin{aligned}
& \sigma(k)=\left[\begin{array}{ll}
S_{1} & S_{2}
\end{array}\right]\left[\begin{array}{c}
\bar{x}_{1}(k) \\
\bar{x}_{2}(k)
\end{array}\right]=0 \\
& S_{1}=K+Q_{22}^{-1} Q_{21,} \quad S_{2}=I, \\
& K=\left(Q_{22}+\Phi_{12}^{T} P \Phi_{12}\right)^{-1} \Phi_{12}^{T} P \Phi_{11}^{*}
\end{aligned}
$$

で与えられる ${ }^{8,14)}$ こここで $I$ は単位行列, $\boldsymbol{P}$ は離散型リカ ツチ方程式

$$
\begin{aligned}
& \boldsymbol{P}-\Phi_{11}^{* T} \boldsymbol{P} \Phi_{11}^{*}+\Phi_{11}^{* T} \boldsymbol{P} \Phi_{12}\left(\boldsymbol{Q}_{22}+\Phi_{12}^{T} \boldsymbol{P} \Phi_{12}\right)^{-1} \Phi_{12}^{T} \boldsymbol{P} \Phi_{11}^{*} \\
& \quad-\boldsymbol{Q}_{11}^{*}=\mathbf{0} \\
& \Phi_{11}^{*}=\Phi_{11}-\Phi_{12} Q_{22}^{-1} Q_{12}^{T}, \quad Q_{11}^{*}=Q_{11}-Q_{12} Q_{22}^{-1} Q_{12}^{T}
\end{aligned}
$$

の正定対称唯一解である。また，閉ループ

$$
\bar{x}_{1}(k+1)=\left(\Phi_{11}-\Phi_{12} S_{2}^{-1} S_{1}\right) \bar{x}_{1}(k)
$$

の極を中心 $\alpha+j 0$, 半径 $r(r \leq 1)$ の小円板内に配置させる には $\boldsymbol{P}$ を離散型りカッチ方程式

$$
\begin{aligned}
P & -\frac{\left(\Phi_{11}^{*}-\alpha I\right)^{T}}{r} P \frac{\left(\Phi_{11}^{*}-\alpha I\right)}{r} \\
& +\frac{\left(\Phi_{11}^{*}-\alpha I\right)^{T}}{r} P \frac{\Phi_{12}}{r}\left(Q_{22}+\frac{\Phi_{12}^{T}}{r} P \frac{\Phi_{12}}{r}\right)^{-1} \frac{\Phi_{12}^{T}}{r} P \frac{\left(\Phi_{11}^{*}-\alpha I\right)}{r} \\
& -Q_{11}^{*}=0
\end{aligned}
$$

の正定対称唯一解として与えれば良い15)。状態変数 $\boldsymbol{x}(k)$ での表記では式(12)は

$$
\sigma(k)=S x(k)=0, \quad S=\left[\begin{array}{ll}
S_{1} & S_{2}
\end{array}\right] T
$$

となる。この超平面でスライディングモードを生じさせる と、評価関数 $J_{\mathrm{d}}$ を最小にする制御系を構成することがで
きる。

3.2 コントローラの設計 制御入力は線形状態フィー ドバック制御項 $\boldsymbol{u}_{\mathrm{eq}}$ と非線形制御項 $\boldsymbol{u}_{\mathrm{n} 1}$ で構成され

$$
\begin{aligned}
& \boldsymbol{u}(k)=\boldsymbol{u}_{\mathrm{eq}}(k)+\boldsymbol{u}_{\mathrm{nl}}(k) \\
& \boldsymbol{u}_{\mathrm{eq}}(k)=-\boldsymbol{K}_{\mathrm{eq}} \boldsymbol{x}(k), \quad \boldsymbol{K}_{\mathrm{eq}}=(\boldsymbol{S} \Gamma)^{-1} \boldsymbol{S}(\Phi-\boldsymbol{I}) \\
& \boldsymbol{u}_{\mathrm{nl}}(k)=-\boldsymbol{K}_{\mathrm{nl}} \boldsymbol{x}(k), \quad \boldsymbol{K}_{\mathrm{nl}}=\eta(\boldsymbol{S} \Gamma)^{-1} \boldsymbol{S}
\end{aligned}
$$

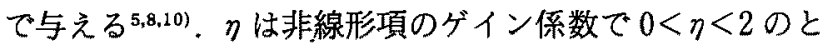
き，切換超平面 $\sigma(k)=0$ 上に状態が到達することが保証 される5゙.

\section{4. 点火選択の定式化と単純選択アルゴリズム}

本章では，インパルス制御源の点火選択の定式化と選択 に用いる単純選択アルゴリズム（SSA）を提案する．以 下では，位置 1 の制御源を例にとるが，位置 2 でも同様で ある。

4.1 定式化 インパルス制御源の点火選択の定式化の ために第 3 図を参照して制御力を幾つかの行列に分解し，

$$
\begin{aligned}
& {\left[\begin{array}{l}
F_{y} \\
F_{z}
\end{array}\right]=\boldsymbol{D G F}} \\
& \boldsymbol{D}=\left[\begin{array}{llllll}
\boldsymbol{D}_{1} & \boldsymbol{D}_{2} & \cdots & \boldsymbol{D}_{\boldsymbol{k}} & \cdots & \boldsymbol{D}_{\mathrm{n}_{\mathrm{col}}}
\end{array}\right] \text {, } \\
& \boldsymbol{G}=\operatorname{diag}\left[\begin{array}{llllll}
\delta_{1} & \delta_{2} & \cdots & \delta_{j} & \cdots & \delta_{n_{\mathrm{at1}}}
\end{array}\right] \\
& \boldsymbol{F}=\left[\begin{array}{llllll}
F_{1} & F_{2} & \cdots & F_{j} & \cdots & F_{n_{\mathrm{a} 11}}
\end{array}\right]^{T} \\
& \text { とする.ここで, }
\end{aligned}
$$

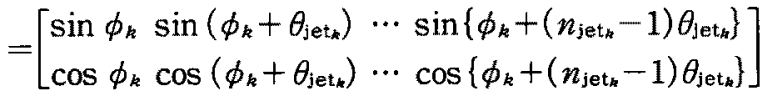

$$
\begin{aligned}
& \left(k=1,2, \cdots, n_{\text {col }}\right) \\
& \delta_{j}\left\{\begin{array}{l}
1 \text { ( } j \text { 番インパルス制御源 on の場合) } \\
0 \text { ( } j \text { 番インパルス制御源 off } \text { の場合 })
\end{array}\right. \\
& \left(j=1,2, \cdots, n_{\text {al1 }}\right)
\end{aligned}
$$

$n_{\mathrm{col},}, n_{\mathrm{all}}$ は制御源の列数と個数である。また，行列 $\boldsymbol{D}$ は 各制御源を $Y_{\mathrm{B}}, Z_{\mathrm{B}}$ 軸に分解する行列，行列 $\boldsymbol{G}$ は制御源 の on, off（ $j$ 番制御源が on の場合は $\delta_{j} か ゙ 1$, off なら 0 ) を決める行列，行列 $\boldsymbol{F}$ は制御源の推力を要素とする行列 である。

4.2 単純選択アルゴリズム（SSA）の解析手順 点 火選択アルゴリズムとして SGA は最適な組合せを広く探 索することができる6 が.ランダムサーチの確率的な探索 のため反復計算が必要とされ，実時間で計算するには並列 計算チップ等の工夫が必要とされる欠点がある，本節で は, SGAに比べ計算時間が非常に少ない単純選択アルゴ リズムを提案する。

その概要は制御系から要求された制御力 $\boldsymbol{F}_{\mathrm{Inp}}$ に最も近 いインパルス制御源を 1 つ選び，この制御源で不足分の制 御力をまた 1 つ選ぶという手順を数回繰り返し，点火する 制御源を選択していく方法である.

これを具体的に説明すると第 1 回目の反復では，制唯系 


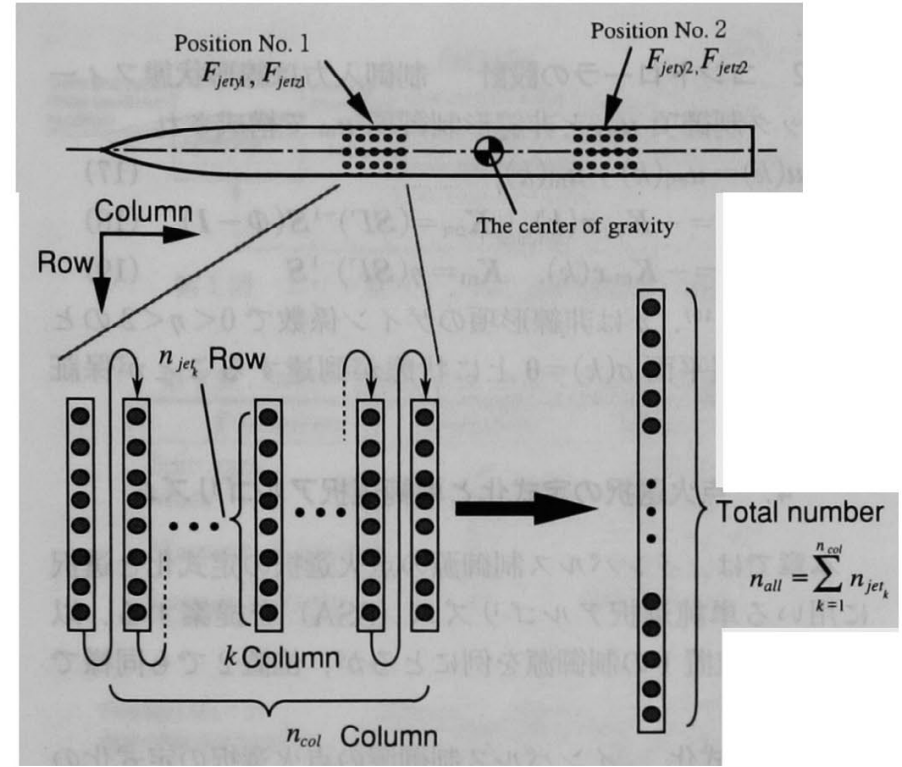

（a）インパルス制御源の配置

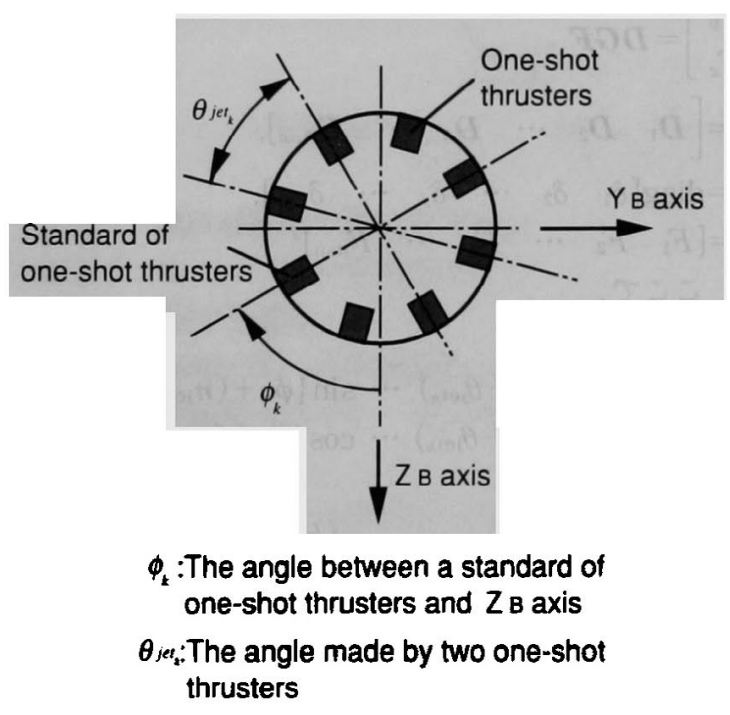

(b) 列の断面図

第 3 図 インパルス制御源の点火選択の定式化の説明図

から要求された制御力 $F_{\text {Inp }}$

$$
f_{\text {Inp }}(0)=F_{\text {inp }}
$$

とし,

$$
\left\|f_{\text {inp }}(0)-f_{k}\right\|_{2}
$$

が最小となる $\boldsymbol{f}_{\boldsymbol{k}}$ を見つけ $\boldsymbol{f}_{\mathrm{ch}}(1)=\boldsymbol{f}_{k}$ とし, 点火制御源の

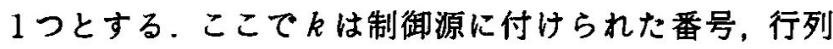
$f_{k}$ は

$$
\begin{aligned}
& \boldsymbol{f}_{k}=\boldsymbol{D} \boldsymbol{g} \boldsymbol{f} \\
& \boldsymbol{g}=\operatorname{diag}\left[\begin{array}{llllll}
\delta_{1 k} & \delta_{2 h} & \cdots & \delta_{j k} & \cdots & \delta_{n_{\mathrm{an1}} k}
\end{array}\right] \\
& \boldsymbol{f}=\left[\begin{array}{llllll}
f_{1} & f_{2} & \cdots & f_{j} & \cdots & f_{n_{\mathrm{a} 11}}
\end{array}\right]^{T}=\boldsymbol{F} \\
& \delta_{j k}=\left\{\begin{array}{llll}
1 & j=k \\
0 & j \neq k
\end{array}\right.
\end{aligned}
$$

であり，行列 $\boldsymbol{f}$ と行列 $\dot{D}$ は式(20) と同様に推力を要素と する行列と各制御力を $Y_{\mathrm{B}}, Z_{\mathrm{B}}$ 軸に分解する行列でる.

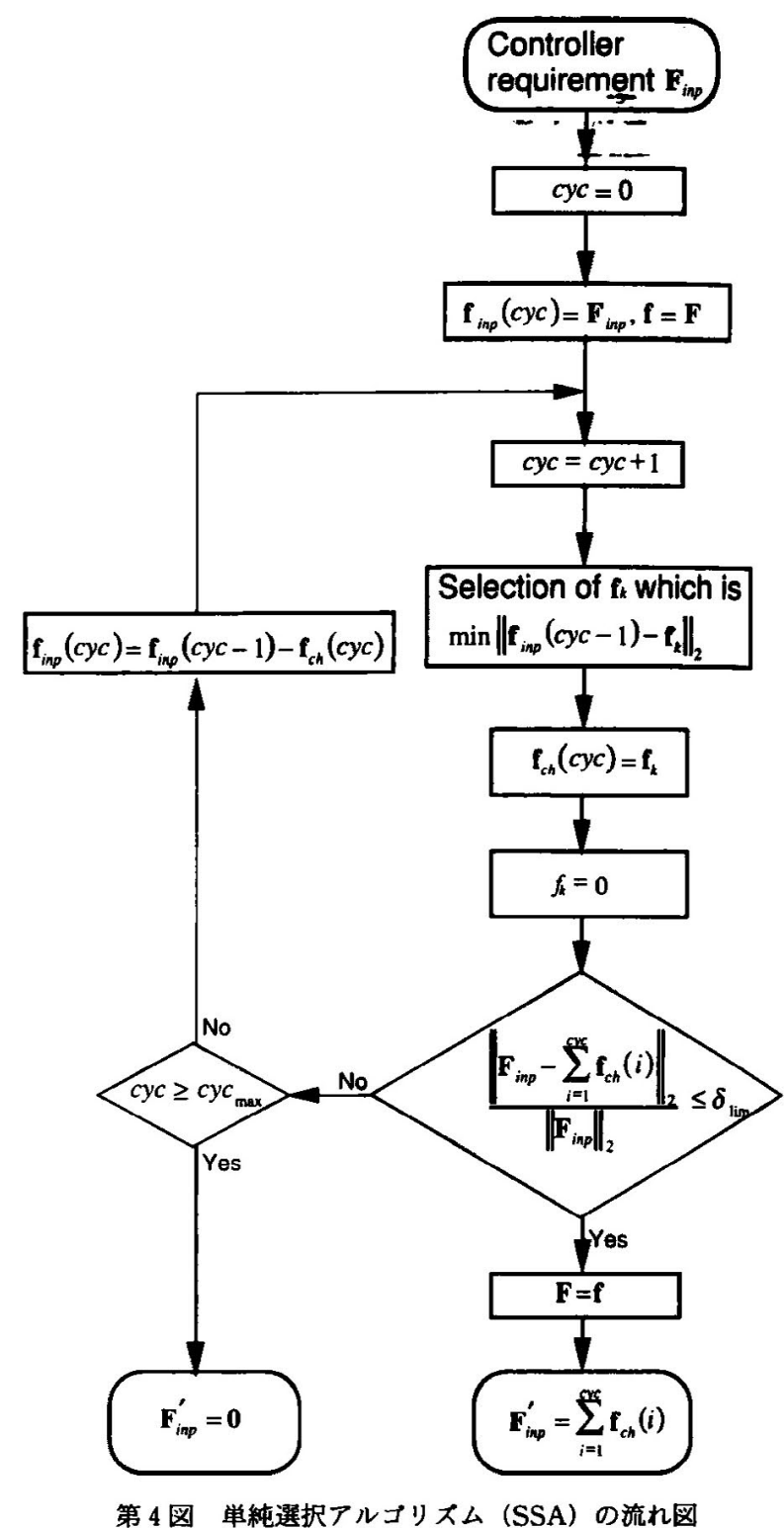

そして判定条件

$$
\frac{\left\|F_{\text {inp }}-\boldsymbol{f}_{\mathrm{ch}}(1)\right\|_{2}}{\left\|\boldsymbol{F}_{\text {inp }}\right\|_{2}} \leqq \delta_{\mathrm{llm}}
$$

（ $\delta_{11 \mathrm{~m}}$ ：予め設定する判定值）を満たしていれば $\boldsymbol{f}_{k}$ のみを 点火し，満たしていなければ

$$
f_{\text {inp }}(1)=f_{\text {inp }}(0)-f_{\text {ch }}(1)
$$

として式(24)〜 (27) と同様な操作を決められた反復回数 $c y c_{\text {max }}$ まて綠り返す。最終的に判定条件が満足されなけ ればこの回の制御はしないこととする.この手順の流れ図 を第 4 図に示す．以下の解析では， $\delta_{11 \mathrm{~m}}=0.2$ とした.

\section{5. 解 析 結 果}

本章ては 3 章の制御系を 2.2 節の線形化モテルの噰散時 間系て超平面の設計の後, その制御系を 2.1 節の連続時間 系の非線形解析モデルへ適用する．ここで超平面は消費し た推力が少なくなるように選ばれる。 
第 2 表 極配置と制御間隔をパラメータとした解析ケース

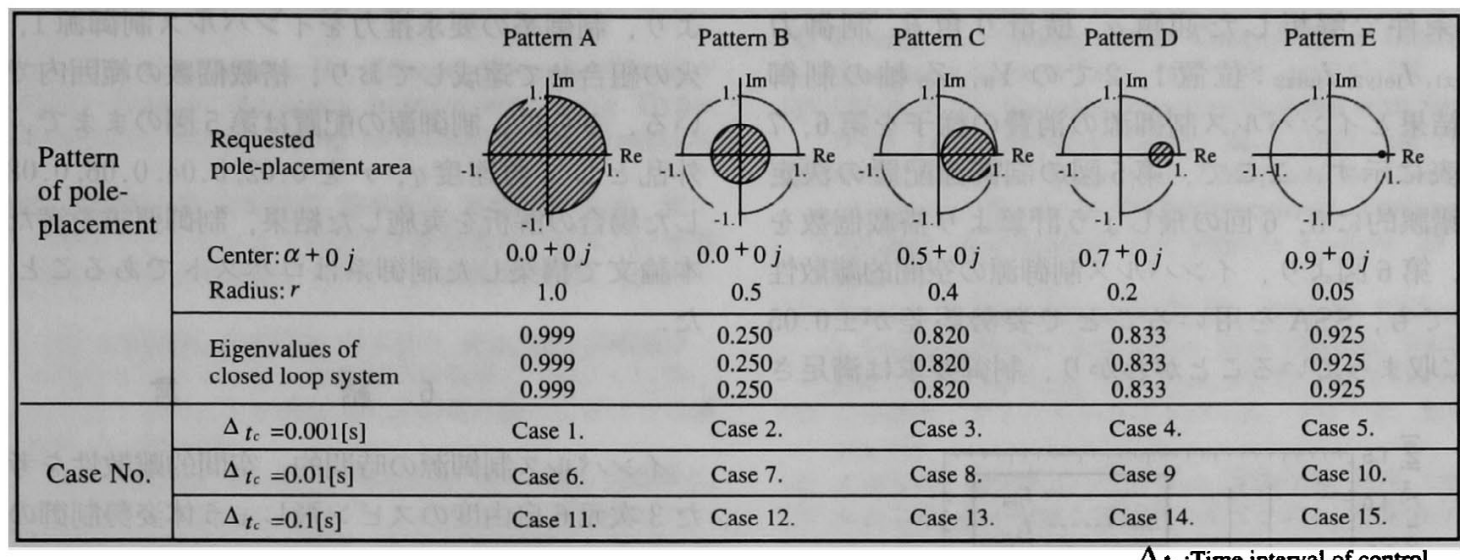

第 3 表 各ケースでのインパルス制御源の消費推力

\begin{tabular}{|c|c|c|c|c|c|c|}
\hline \multirow{12}{*}{$\begin{array}{l}\text { Thrust } \\
\text { consumption } \\
\quad \text { [Ns] }\end{array}$} & Case No. & Case 1. & Case 2. & Case 3. & Case 4. & Case 5. \\
\hline & $Y_{B}$ direction & 10.73 & 1.025 & 3.173 & 3.337 & 5.152 \\
\hline & $Z_{B}$ direction & 10.73 & 1.036 & 2.432 & 2.590 & 4.572 \\
\hline & Total & 21.46 & 2.061 & 5.605 & 5.927 & 9.724 \\
\hline & Case No. & Case 6. & Case 7. & Case 8. & Case 9 & Case 10. \\
\hline & $Y_{B}$ direction & 93.45 & 4.856 & 6.512 & 7.092 & 16.50 \\
\hline & $Z_{B}$ direction & 83.14 & 1696 & 9.869 & 3.677 & 11.10 \\
\hline & Total & 176.6 & 1701 & 10.73 & 10.77 & 27.60 \\
\hline & Case No. & \multicolumn{5}{|c|}{ Case 11. Case 12. Case 13. Case 14. Case 15.} \\
\hline & $Y_{B}$ direction & 317.1 & - & 4.043 & 4.367 & 10.08 \\
\hline & $Z_{B}$ direction & 168.5 & - & 40.83 & 13.42 & 8.110 \\
\hline & Total & 485.6 & 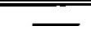 & 44.87 & 17.79 & 18.19 \\
\hline
\end{tabular}

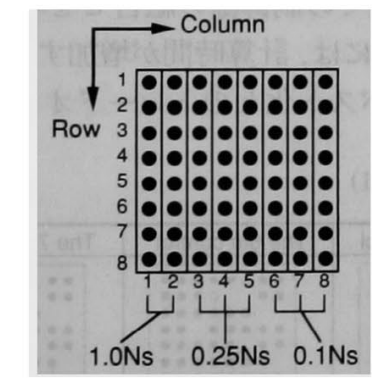

第 5 図 インパルス制御源の配置

\section{1 離散時間系線形モテルへの適用（切換超平面の設} 計）式(6)に第 1 表の飛しょう体諸元 $\left(U_{0}=300 \mathrm{~m} / \mathrm{s}\right.$ と する）と月での重力加速度 $g=1.6464 \mathrm{~m} / \mathrm{s}^{2}$ を代入し，サ

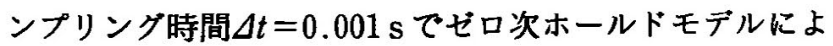
り離散化する。このモデルに極指定範囲と制御時間間隔： $\Delta t c$ をパラメータとして 3 章の制御系を用いる. 解析ケー スを第 2 表に示す、ここで第 2 表の閉ループ固有值とは， 指定された極配置範囲から前章の解析手順て決定された超 平面を用いた場合の行列 $\left(\Phi_{11}-\Phi_{12} S_{2}^{-1} S_{1}\right)$ の固有値てあ る. 3 章の制御系は, 状態空間モデルのサンプリング時間 で制御器も作動することが前提になっているが、この前提 を満たさない場合（Case 6〜15）においてもこの制御系の ロバスト性を確認するために制御時間間隔をパラメータと

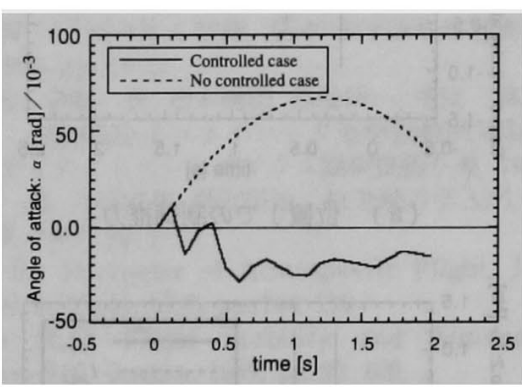

（a）迎角の時間変化

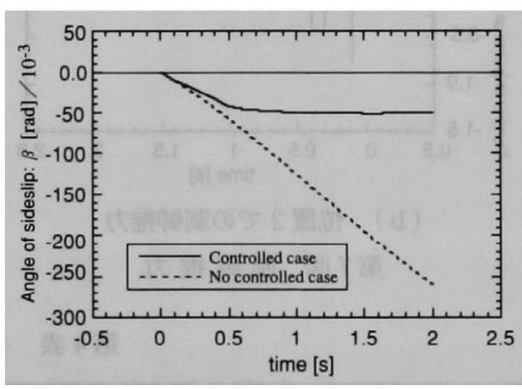

（b）横滑り角の時間変化 第 6 図 飛しょう解析結果例

した. 各ヶースで初期外乱を $q=r=0.1 \mathrm{rad} / \mathrm{s}$, それ以外 の状態変数を 0 ，式(9)の行列 $\boldsymbol{Q}$ を

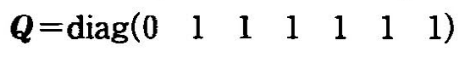

として解析した．各ケースで 2 秒間制御した場合の消費推 力の結果を第 3 表に示す．それぞれの $\Delta t_{\mathrm{c}}$ で消費推力が最 小になるケース [ケース 2,ケース 8,ケース 14] が存在 し，その極指定範囲が異なっている。これより， $\Delta t_{\mathrm{c}}$ に応 して極指定をすることで消費推力を小さくてきることが確 認できる。

5.2 連続時間系非線形解析モデル人の適用 前節で設 計した切換超平面とコントローラを制御系に用い，位置 1，2のインパルス制御源の配置は同じとし，その配置は 第 5 図に示すように $8 \times 8$ の計 64 個（位置 1,2 で計 128 個）搭載し，同じ列には同じ力積の制御源を等間隔 $\left(\theta_{\mathrm{jet}}=45^{\circ}\right)$ に配置する、また，制御間隔を $0.1 \mathrm{~s}$ ，初期外 
乱としてピッチとヨーの角速度 $q, r を 0.1 \mathrm{rad} / \mathrm{s}$ とす る.この条件で解析した迎角 $\alpha$ ，横滑り角 $\beta$ ，制御力 $\left(I_{\text {jety1 }}, I_{\text {jetz1 }}, I_{\text {jety2 } 2}, I_{\text {jetz2 }}\right.$ : 位置 1,2 で $Y_{\mathrm{B}}, Z_{\mathrm{B}}$ 軸の制御 力積）の結果とインパルス制御源の消費の様子を第 6,7 図と第 4 表に示すここで，第 5 図の制御源配置の決定 は，試行錯誤的に5，6回の飛しょう計算より搭載個数を 決定した。第 6 図より，インパルス制御源の空間的離散性 を考慮しても，SSAを用いることで姿勢誤差が士0.05 $\operatorname{rad}$ 以内に収まっていることがわかり，制御要求は満足さ

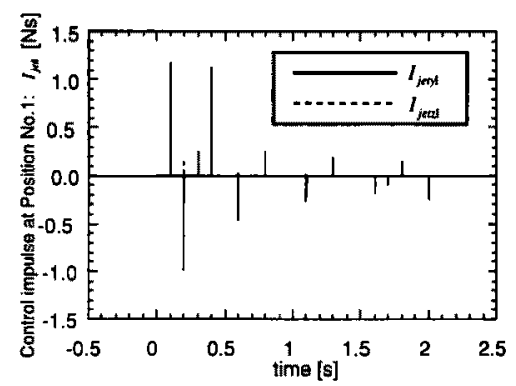

(a) 位置 1 での制御推力

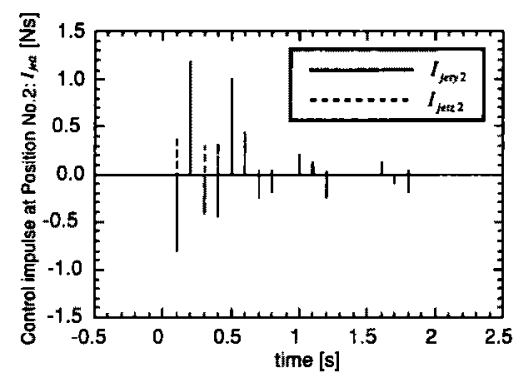

（b） 位置 2 での制御推力 第7図制御推力
れている。また，第 4 表のインパルス制御源の消費の様子 より, 制御系の要求推力をインパルス制御源 $1 ， 2$ 個の点 火の組合せで達成しており，搭載個数の範囲内で収まって いる，さらに，制御源の配置は第 5 図のままで，他の初期 外乱として角速度 $q, r$ を $0.02,0.04,0.06,0.08 \mathrm{rad} / \mathrm{s}$ と した場合の解析を実施した結果, 制御要求を満たしており 本論文で構築した制御系はロバストであることを確認し た。
6. 結
言

インパルス制御源の時間的，空間的離散性を考慮に入れ た 3 次元 6 自由度のスピン飛しょう体姿勢制御のレギュレ 一夕問題の数值解析にスライデイングモード制御と本論文 で提案したSSA を適用し，以下のことが確認できた。

（1）スピン飛しょう体の制御系にスライティングモー ド制御は有効である。

（2）切換超平面の設計において，2 次形式評価関数を 最小化する最適制御問題に極配置を考慮することで消 費する制御量を小さくすることができる。

（3）インパルス制御源の点火選択に本論文で提案した (SSA : Simple Selection Algorithm) を適用する方 法は有効である。

今後, どれだけの推力のインパルス制御源を何個装備す るかという最適配置の考察が必要である。また，入手でき る状態変数の制限, センサ誤差や制御時間遅れ等の外乱も 考慮する必要がある。さらに，SSAのロバスト化のため には， 1 回の反復での制御源の組合せを増やすことが考え られる.この場合には，計算時間が増加するため制御源の組 合せの個数とロバスト化とのトレードオフが必要である.

第 4 表 インパルス制御源の消費の様子（位置 1)

\begin{tabular}{|c|c|c|c|c|c|c|}
\hline The ist control & The 2nd control & The 3rd control & The 4th control & The 5th control & The 6th control & The 7th control \\
\hline 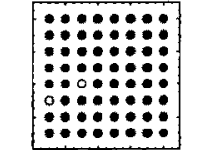 & 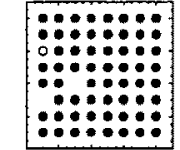 & 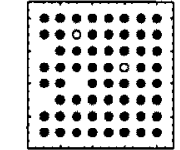 & 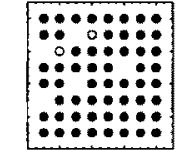 & 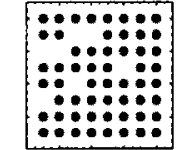 & 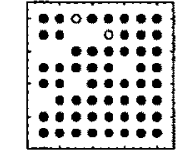 & 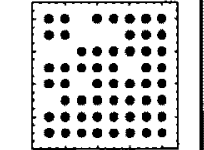 \\
\hline $\begin{array}{l}\text { The number of } \\
\text { remained thrusters } \\
\text { The number of } \\
\text { consumed thrusters } 2\end{array}$ & $\begin{array}{r}62 \\
1\end{array}$ & $\begin{array}{r}61 \\
2\end{array}$ & $\begin{array}{r}59 \\
2\end{array}$ & $\begin{array}{r}57 \\
0\end{array}$ & $\begin{array}{r}57 \\
2\end{array}$ & $\begin{array}{r}55 \\
0\end{array}$ \\
\hline The 8th control & The 9th control & The toth control & The 11th control & The 12th control & The 13th control & The 14th control \\
\hline & & 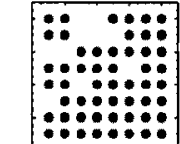 & 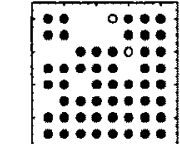 & & & 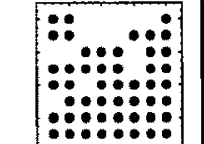 \\
\hline $\begin{array}{r}55 \\
1\end{array}$ & $\begin{array}{r}54 \\
0\end{array}$ & $\begin{array}{r}54 \\
0\end{array}$ & $\begin{array}{r}54 \\
2\end{array}$ & $\begin{array}{r}52 \\
0\end{array}$ & $\begin{array}{r}52 \\
2\end{array}$ & $\begin{array}{r}50 \\
0\end{array}$ \\
\hline The 15th control & The 16 th control & The 17th control & The 18th control & The 19th control & The 20th control & Note \\
\hline 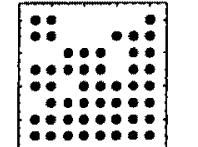 & $\because: \because: \because: 3:$ & 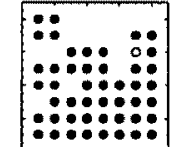 & $\begin{array}{l}\because \\
\because \bullet:\end{array}$ & 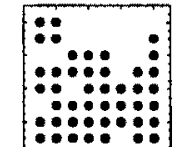 & 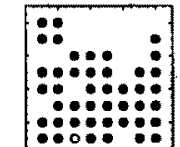 & $\begin{array}{l}\text { Remained } \\
\text { thrusters }\end{array}$ \\
\hline $\begin{array}{r}50 \\
0\end{array}$ & $\begin{array}{r}50 \\
2\end{array}$ & $\begin{array}{r}48 \\
1\end{array}$ & $\begin{array}{r}47 \\
2\end{array}$ & $\begin{array}{r}45 \\
0\end{array}$ & $\begin{array}{r}45 \\
1\end{array}$ & \\
\hline
\end{tabular}




\section{参 考 文 献}

1) Yamanaka, T. and Tanaka, H.: Effects of Impulse Thruster on Exterior Ballistic Accuracy Improvement for a Hyper Velocity Rocket, 16th Int. Symp. on Ballistics, San Francisco, 1996.

2）泉頭悦郎, 高梨咺一郎, 吉田昭彦, 菊本浩介, 高橋龍雄, 山中 勉: 飛しょう体のサイドジェットの空力干涉効果について(1)実飛 しょう試験，第 35 回荊行機シンポジウム講演集，1997, pp. 265268.

3）高梨晋一郎, 泉頭悦郎, 吉田昭彦, 菊本浩介, 徳永英紀, 高橋龍雄： 飛しょう体のサイドジェットの空力干涉奻果について(2)湬し よう体に作用する力による推定, 第 35 回飛行機シンポジウム講 演集, 1997, pp. 269-272

4）高梨晋一郎，泉頭悦郎，吉田昭彦，菊本浩介，田中秀樹，関野展弘， 日高義徳：飛しょう体のサイドジェットの空力干涉効果につい て（3）圧力場の相似則による推定, 第 35 回飛行機シンポジゥム 講演集, 1997, pp. 273-276.

5）田中秀樹，狼 嘉彰：インパルス制御源を用いたスピン飛しょう 体の姿勢制御 (第 1 報)，日本機械学会論文集， C 編，64，621 (1998), pp. 1699-1706.

6）田中秀樹，松永三郎，狼 嘉彰：インパルス制御源を用いたスピ ン飛しょう体の姿勢制御（第 2 報），日本機械学会論文集， C 編， 64, 622 (1998), pp. 2026-2032.

7）田中秀樹，狼 嘉彰、松永三郎：インパルス制御源を用いたスピ ン飛しょう体の姿勢制御，第 41 回宇宙科学技術連合講演会講演 集, 1997, pp. 217-222.

8）野波健蔵，田 宏奇：スライディングモード制御，コロナ社, 東 京, 1994, pp. 190-203.

9）野波健蔵, 田 宏奇：ロバスト最小次元VSSオブザーバを適用 した弾性ロータ・磁性軸受系のスライディングモード制御，旦本 機械学会論文集, C 編, 60, 571 (1994), pp. 897-905.
10）增淵正美，川田誠一：システムのモデリングと非線形制御，コロ ナ社, 東京, 1996, pp. 209-226.

11) Furuta, K.: Sliding Mode Control of a Discrete System, Systems \& Control Lett., 14 (1990), pp. 145-152.

12) Utkin, V. I.: Variable Structure Systems with Sliding Modes, IEEE Trans. Automat. Contr., 22, 2 (1977), pp. 212-222.

13) Utkin, V. I. and Yang, K. D. : Methods for Constructing Discontinuity Planes in Multidimensional Variable Structure Systems, Automation and Remote Control, 39 (1978), pp. 1466-1470.

14) Piper, J. K. and Surgenor, B. W. : Discrete Sliding Control of a Coupled-Drives Apparatus with Optimal Sliding Surface and Switching Gain, IEE Proc. Pt. D, 140, 2 (1993), pp. 70-78.

15）古田勝久：ディジタルコントロール，コロナ社, 東京, 1989, pp. 116-150.

16）北野宏明：遺伝的アルゴリスム, 産業図書, 東京, 1993, pp. 3-29.

17）坂和正敏, 田中雅博：遺伝的アルゴリスム, 朝倉書店, 東京, 1995, pp. 1-31.

18）デービス，L. 編（嘉数侑昇注か訳）：遭伝的アルコリズムハンド ブック，䔉北出版，東京, 1994, pp. 106-119.

19）中島 俊：LUNAR-A 計画, 第 40 回宇宙科学技術連合講演会講 演集, 1996, pp. 13-17.

20）森田泰弘, 中島 俊, 橋本樹明, 馬場研一, 寺田 博, 白川健一, 阿 部健一：LUNAR-A ペネトレー夕姿勢制御系の開発, 第 5 回ア ストロダイナミクスシンポジウム講演後刷り集, 1995, pp. 71-76.

21）加藤寛一郎, 大屋昭男, 柄沢研治: 航空機力学入門, 東京大学出版 会, 東京, 1982, pp. 1-74.

22) Etkin, B.: Dynamics of Atmospheric Flight, John Wiley \& Sons, New York, 1972, pp. 104-195.

23) Nelson, R.C.: Flight Stability and Automatic Control, McGraw-Hill, Boston, 1989, pp. 83-109.

24) Ashley, H.: Engineering Analysis of Flight Vehicles, Dover Publications, New York, 1974, pp. 27-46. 